332.3

\author{
. ньків \\ ьвівський н ціон льний університет імені в н \\ вул. . орошенк, 41, м. ьвів, 79000, кр їн
}

бгрунтов но трив лість р ннього ет пу землекористув ння в кр їні т в його меж х, виділено дв періоди н підст ві вр хув ння перев жних форм землекористув ння, способів і зн рядь обробітку землі, форм вл сності н основний з сіб виробництв ; про н лізов но особливості використ ння земельного фонду.

лючові слов : землекористув ння, форми вл сності, ет п.

т новлення т розвиток людського суспільств нерозривно пов'яз ні з використ нням природних ресурсів, основну ч стину у структурі яких ст новлять земельні, які зумовлюють існув ння т використ ння всіх інших видів ресурсів. тже, будь-які види природокористув ння передусім треб розгляд ти як землекористув ння. історичному процесі ст новлення землекористув ння зн чення земельних ресурсів еволюціонув ло від просторового б зису для переміщення т місця концентр ції корисних коп лин до основного з собу і предмет пр ці в сільському т лісовому господ рстві. нтенсивність використ ння земельних ресурсів зн чно з лежить від рівня розвитку продуктивних сил, ефективність - від рівня зн нь про об'єКт використ ння т його зн чення для природного середовищ і людського суспільств .

нній ет п ст новлення землекористув ння в меж х території кр їни є н йтрив лішим у ч совому вимірі, оскільки трив в від ч су з кінчення льодовикового періоду до поч тку V ст., коли з метою підвищення ефективності використ ння землі, опод ткув ння якої д в ло основні н дходження в ск рбницю, розпоч то перше реформув ння використ ння укр їнських земель, які були під вл дою еликого нязівств итовського т ечі осполитої. сновним з вд нням реформи землекористув ння був дет льний облік земель усіх к тегорій господ рств і підвищення їхньої продуктивності для збільшення виробництв тов рної продукції.

н чн трив лість р ннього ет пу землекористув ння, недост тність відомостей про особливості ведення господ рств , які грунтуються, головно, н результ т х рхеологічних досліджень, д ють змогу виділити в його меж х дв періоди н підст ві вр хув ння перев жних форм землекористув ння, способів і зн рядь обробітку землі, форм вл сності н основний з сіб виробництв т н явних к тегорій з лежного н селення.

еріод (7 тис. років до н.е.-перш половин тис. н.е.)-поступовий перехід від привл снюв льного до відтворюв льного землекористув ння, ст новлення тимч сових центрів землеробств з екстенсивним способом використ ння землі і природним відновленням родючості, домінув нням тв ринництв .

(C) НьКів ., 2012 
ершим крок м ст новлення людського суспільств , його виокремленню з природного середовищ вл стив повн з лежність людини від природних умов, кількості т якості природних ресурсів, що зумовило повне п нув ння в період п леоліту і мезоліту привл снюв льних способів землекористув ння (мисливство і збир льництво). кий спосіб господ рюв ння обмежув вся природними чинник ми, оскільки від природи не можн взяти більше, ніж вон може д ти, що лімітув ло ефективність людської діяльності, кількість продуктів х рчув ння, їхню різном нітність і, відповідно, кількість н селення т под льший поступ льний розвиток.

рдин льні зміни природних умов після з кінчення льодовикового періоду (близько 10 тис. років тому) позн чились потеплінням, зникненням певних видів флори і ф уни, що потребув ло від людського суспільств д пт ції. ояв певних предст вників тв ринного і рослинного світу, що були корисними для людини і прид тними для доместик ції, слугув ло основою для розвитку відтворюв льного землекористув ння, яке д ло людині змогу по-новому використовув ти сили природи, окультурюв ти т ктивізув ти, відтворюв ти і примножув ти їі можливості.

кщо під ч с тот льного п нув ння привл снюв льного землекористув ння людин , головно, використовув л ті природні ресурси, які не потребув ли від неї ніякого вдоскон лення (клім тичні, водні, ресурси рослинного і тв ринного світу), то із переходом до відтворюв льного способу господ рюв ння щор 3 ктивнішу роль поч ли відігр в ти земельні ресурси як предмет і з сіб пр ці у ході ведення землеробств і тв ринництB .

твердженням · вілов , первинні осередки відтворюв льного землекористув ння (землеробство і скот рство) були х р ктерні для ередньої зії, де окультурено хлібні зл ки, бобові т одом шнено велику і дрібну рог ту худобу, свиней, вже звідси цей спосіб господ рюв ння поширився н територію вропи, у тому числі й н $[15,55,23]$.

емлеробство і скот рство д ло людству перспективи для збільшення кількості продуктів х рчув ння, головне - можливість контролю їхнього виробництв . озвиток землеробств стимулюв в перехід до осілого способу життя, що вивільнило ч с, який витр ч ли н полюв ння, для вл штув ння побуту т низки вин ходів (прядіння і тк цтво, будівельн спр в , гонч рство, мет лургія). поч ткув ння відтворюв льного землекористув ння зумовило зміни не тільки в м тері льній, й у духовній сфері. оловним трибутом духовності людини ст л земля, що д є урож й, т тмосферні явищ , від яких з лежить його кількість т продуктивність худоби [10].

ерші землероби т скот рі з'явилися в вропі не пізніше 7 тис. років до н.е. у івнічній реції т поступово поширились н весь лк нський регіон, Згодом по всій ередній вропі, у тому числі й н суч сній території кр їни, що з свідчено рхеологічними зн хідк ми різном нітних культур (буго-дністерської, лінійно-стрічкової кер міки). селяння в цей період з безпечув ло себе продукт ми х рчув ння передусім з вдяки мисливству, риб льству і збир льництву, проте біля тимч сових стоянок 3 сів ли невеликі ділянки зл ковими культур ми т вип с ли худобу, утримув ли свиней. еличезні нез селені простори сприяли швидкому переселенню н нові місця т веденню екстенсивного землекористув ння, що було стримув льним чинником для н копичення здобутків, які 6 привели до переходу суспільств н новий щ бель розвитку.

ля періоду енеоліту в меж х кр їни х р ктерний перший розквіт відтворюв льного способу землекористув ння, що було зумовлене використ нням мет левих (мідних) зн рядь т впров дженням підсічного землеробств, яке позн чилось н співвідно- 
шенні площ лісів і степу. цей період рут- ністерське межиріччя з йм ли носії трипільської культури, що прийшли з івденно- хідної р нсільв нії. я культур з яскр во вир женим землеробським х р ктером існув л близько 2,5 тис. років т охопил м йже всю пр вобережну лісостепову територію кр їни, розвинувшись у яскр ве т м сшт бне явище [2, 16]. цей період розвив лося рільництво, де використовув ли тяглову силу волів, збільшув лися розміри поселень, зрост л їхня кількість, покр щув вся побут. сі економічні успіхи трипільців грунтув лись н екстенсивному землекористув нні (періодичне освоєння нових земель). елик кількість поселень бул зумовлен коротким періодом їхнього існув ння (70-80 років), коли після висн ження ресурсів общин перебир л сь н нове місце.

рипільськ систем екстенсивного землекористув ння, освоївши н йбільш прид тну для землеробств лісостепову смугу кр їни, потр пил в безвихідь. ішення цієї проблеми потребув ло інтенсифік ції землеробств, впров дження з ходів з відтворення родючості грунтів. роте тодішня культур вибр л господ рську модель, у якій н передові позиції виходило скот рство. рипільці поч ли розселятись 3 межі своєї екологічної ніші ( ісостепу), освоюючи олісся з меншою кількістю прид тних для землеробств площ т івнічно- хідне ричорномор'я, де перев жним типом землекористув ння ст ло кочове скот рство $[6,12,24]$. кщо для н селення ісостепу перехід до скот рств був вимушеним з ходом, зумовленим кризою землеробств, то в степу цей н прям був основним з поч тку з родження відтворюв льного землекористув ння, що визн ч лось безмежними п совищ ми, в жкими для ручного обробітку грунт ми т посушливістю клім ту.

період середньої бронзи (кінець -поч ток тисячоліття до н. е.) н території кр їни м йже повсюди простежув л ся ктивіз ція землеробств , що було спричинене необхідністю здол ти моног лузевість господ рств, подол ти проблему нест чі хліб т з безпечити поступ льний розвиток. ьому процесу сприял ктивіз ція бронзової мет лургії, впров дження орного землеробств . езв ж ючи н ктивіз цію землеробств, в суспільних угрупов ннях скот рство з лиш лось провідною г луззю діяльності. озділення спільноти сприяло збільшенню рухливості т розширенню плош п совищ, оскільки зменшил сь кількість людей, які пересув лись р зом з худобою.

ільш ч стин общини мешк л в поселеннях, 3 йм ючись землеробством і з готівлею кормів н зиму. кий поділ ст в основою ведення комплексного господ рств , яке в степовій зоні з кінчилось кризою. сновн причин з неп ду одноч сного ведення землеробств і скот рств у степу прихов н у відсутності зн нь ін вичок відновлення родючості земель, ведення інтенсивного господ рств , що потребув ло розорюв ння нових площ i, відповідно, скорочення п совищ, що підрив ло кормову б зу скот рств . ирубув ння дерев для потреб будівництв , оп лення ремісничого виробництв спричинюв ло обміління рік, висих ння степу, що погіршув ло екологічну ситу цію.

рубежі II-I ст. до н. е. в різних ч стин х кр їни сформув лись три різні моделі господ рюв ння, які відрізнялися етнічною н лежністю, мент льністю, способом життя, рівнем розвитку, проте ці відмінності не перешкодж ли існув нню між ними конт ктів і вз ємопроникнення культур. VII ст. до н. е., коли н суч сному острові ерез нь непод лік ч ков було з снов но орисфен, перше поселення еллінської культури, яке н д лі поширилось н все північне узбережжя орного моря, ижнє обужжя, одніпров'я, рівнинні простори риму, н території кр їни поч вся розвиток високопродуктивного поліг лузевого господ рств з осілим способом життя, зерновим господ рством, с дівництвом і виногр д рством, ремесл ми [5]. 
меж х лісостепової смуги кр їни в добу з ліз сформув вся етнічно строк тий світ, з якого згодом виокремились слов'яни, що з йм лися землеробством і м ли тісний зв'язок з еллінською цивіліз цією, як стимулюв л їхній розвиток.

і дв землеробські світи були розділені степовими простор ми, які притягув ли кочове н селення з моног лузевим господ рством, що в пошук х ліпшої екологічної ніші дол ли величезні простори. ихід кочівників н історичну рену в добу з ліз зумовлений 6 г тьм причин ми, у тому числі вин йденням доскон лої вуздечки, як д в л змогу керув ти конем не лише в господ рстві, й у військових поход х $[11,14$, 21]. днобок економік кочівників є вр зливою, тимч сові піднесення їхнього розвитку пов'яз ні із з йняттям вигідної екологічної, соці льної ніші (поряд з розвиненими осілими н род ми), де вони компенсув ли все для ведення господ рств (хліб, ремісничі вироби, р бів, дорогоцінності). ерез степові простори кр їни, почин ючи 3 IX ст. до н. е. і до IV ст. н. е. пройшл низк хвиль кочових спільнот, які змінюв ли одн одну (кіммерійці, скіфи, с рм ти, готи, гунни). они не принесли вищої культури, н томість помітно сповільнили розвиток ремесел, землеробств .

еріод II (друг половин тисячоліття н. $е$-кінець $V \mathrm{~cm}$.$) - формув ння тери-$ торії постійної осілості з мережею городиш (міст) $i$ сіл, перехід від пересувного землеробств з розпушув льною технікою до трипілля з плужною ор нкою $m$ відновлення родючості грунтів з допомогою орг нічних добрив, що г р нтув ло стійлове тв ринництво. ільськогоспод рське землекористув ння доповнюв лось збир льством, мисливством, риб льством і різном нітними промисл ми.

ля поч тку періоду х р ктерн культурн і мовн диференці ція слов'янського н селення, руйнув ння первісно-родових відносин і соці льн диференці ція суспільств н підст ві м йнового розш рув ння. снув ння зн чної з грози від кочового н селення у степовій зоні і риму зумовили концентр цію т поч ток осілого способу життя слов'ян у меж х лісової, лісостепової зони т ередк рп ття, де н поч тку цього періоду поч ли формув тись союзи племен: поляни ( ереднє одніпров'я), древляни ( хідн олинь), сіверяни ( ніпровське івобережжя), волиняни ( хідн олинь), білі хорв ти ( ередк рп ття), уличі ( ижне одніпров'я).

другій половині I тисячоліття в меж х лісової т лісостепової зон кр їни поч лося постійне селітебне землекористув ння, оскільки с ме в цей ч с з'явилися перші укріплені поселення-городищ (більшість яких н д лі тр нсформув л сь у міст ), хоч зн чн ч стин н селення прожив л у відкритих селищ х. кі селищ розміщув лись груп ми н відст ні 0,5-3,0 км т були невеликі з розмір ми (0,5-1,0 г ) і, відповідно, кількістю н селення. ителі т ких селищ з безпечув ли своє існув ння в меж х ресурсної зони, як охоплюв л територію н вколо поселення в р діусі 10-60 хв пересув ння бо, відповідно, 1-5 км від жител [1, 20]. ормув ння д вньосл вянської поселенської структури простежене н прикінці -н поч тку ст. кремі н селенні пункти т їхні скупчення концентрув лися в місцевостях з розвиненою гідрологічною мережею. - ст. 3 г льн кількість поселень збільшил ся, що зумовлено освоєнням нових земель т зрост нням кількості н селення. шестя орд $\mathrm{x}$ H тия в ст. т вироблення ресурсної зони н вколо конкретних поселень зумовили їхнє зникнення $\mathrm{T}$ відновлення пізніше $\mathrm{H}$ новому місці. $\mathrm{K}$ ситу ція бул $\mathrm{x} p$ ктерн не тільки для південно-руських земель, й для північних р йонів хідної вропи т відом як систем “виходу н горби” [10].

ерев жн більшість сільських поселень з фіксов н н меж х великих природних зон, лише п'ят їхня ч стин х р ктерн для середини природних м сивів. межі 
ісостепу і тепу з селення відбув лося примусово з метою створення оборонних поселень т не м ло попереднього підгрунття. кі поселення м ли строк ту демогр фічну структуру т етнічний скл д, формув лись в обмежені терміни і з скл дних зовнішніх умов, тому в їхніх меж х нем озн к розвинених місцевих виробництв. л ндш фтно строк тій межі між поліською т лісостеповою зон ми н д вноосвоєнних і 3 селених територіях простежено розвиток потужних для р ннього середньовіччя виробничих центрів, які м ли тр диції використ ння місцевих природних ресурсів і створюв ли продукцію для територі льного обміну між мешк нцями різних природних зон.

кріплені поселення (городищ ) виник ли, головно, як символ могутності вл ди т були призн чені для з хисту від н п дів, оскільки їх споруджув ли в місцях, н йбільш прид тних для оборони.

евелик площ сільських поселень у період - ст. д є підст ви стверджув ти про їхню м лодвірність (не більше п'яти домогоспод рств), що пояснюють ростом господ рської с мостійності м лих сімей у скл ді гром ди. $\quad$ к тенденція зберіг л сь і в V- V ст. [10]. лицькій землі в V- V ст. сел скл д лись з одного дворищ (одн -три селянські сімї) бо з двох-чотирьох окремих домогоспод рств м лих сімей.

ерев ж ння невеликих сіл ч стково пояснюють природними умов ми (перев жно, м лопродуктивними лісовими грунт ми), які потребув ли підсічно-перелогової системи землеробств т угноєння. роте систем тичне угноюв ння було можливе лише поблизу поселень, що н йефективніше в м лих сел х. еляни, яким не вист ч ло близьких полів, переселялись н нові території, створюючи умови зручного використ ння земель. кож у цей період розп ду великосімейних колективів сприяв процес переходу до системи трипілля, як , н відміну від підсічно-перелогової, не потребув л великої кількості земель т існув ння великосімейних колективів.

$\mathrm{V}$ ст. н олині і в личині основним н ділом селянського господ рств було дворище і, відповідно, сільськ гром д скл д л сь з окремих дворищ, що поступово тр нсформув лись у гром ду двох типів - подвірну і п йову. йов гром д виник л , коли виділені зі скл ду великої м лі сім’ї не відселялись н нове місце, формув ли окремі двори в попередньому поселенні. одрібнення селянських землеволодінь зумовлюв ло формув ння менших н ділів (жерибків і димів). піввл сник ми земельних н ділів були здебільшого родичі, оскільки кожен вл сник міг прод ти свій н діл, то поступово сільськ гром д співвл сників-родичів перетворюв л сь н гром ду співвл сників-скл дників.

б'єдн ння груп домогоспод рств в одне б г тодвірне село приводимо до формув ння скл дних селянських гром д - подвірних. н слідок т кого процесу село н був ло форми не концентричних, розкид них поселень, до скл ду яких входили не лише господ рств , які вийшли з одного розкид ного дворищ , й дими, що виділялися з різних дворищ. кі процеси еволюції волосної гром ди з под льшою іiї тр нсформ цією в гром ду сіл п йового і подвірного зр зк відбув лися н олині, ддніпрянщині, у лицькому ередк рп тті.

ериторію сільської гром ди ст новили освоєні ї̈ член ми орні землі т інші угіддя, що формув лись протягом трив лого ч су і м ли добре відомі межі. ерев жн більшість угідь т ч стин ріллі зі структури земель сел перебув л у спільному володінні гром ди. ром дські землі використовув ли по-різному: для викон ння з г льних селянських повинностей, з доволення спільних потреб сел, їх зд в ли в оренду, вони слугув ли фондом для розширення індивіду льних селянських господ рств. ром д регулюв л не лише використ ння земельних володінь сел , й землекористув ння 
дворовими н діл ми. пров дження трипільної системи і, відповідно, зменшення площ п совищ змушув ло у гром д х з пров джув ти примусові сівозміни, оскільки для вип с ння худоби використовув ли ділянки ріллі, де був зібр ний урож й. ерев жн більшість ріллі н території сільської гром ди перебув л в індивіду льному володінні домогоспод рств. еляни отримув ли свої н діли від 6 тьків, т кі н діли в документ х іменув лись “отчизни”, “дедизни”. р во селянського двору н володіння угіддями грунтув лось н трудовому принципі (першістю розробки цілини). цей період сільськ гром д м л в 3 г льному користув нні не лише різного роду угіддя, й пр во розпорядж тись необробленими цілинними ділянк ми. iï володіння переходили всі з лишені селян ми розроблені землі, які гром д могл спільно обробляти бо зд в ти в оренду.

евіддільною скл довою в еволюції системи землекористув ння є процес формув ння пр вовідносин щодо вл сності т розпорядж ння землею як основним джерелом з безпечення м тері льними бл г ми, дже ж до V ст. 80-90 \% людей жили тільки 3 вдяки використ нню продуктивності землі. території кр їни в V -V ст. н йбільшого розквіту н бул общинн форм вл сності, коли члени общини спільно обробляли т порівну розділяли отрим ний урож й. д лі, з удоскон ленням зн рядь обробітку т системи землеробств общинн форм тр нсформув л сь у сімейно-общинну, що було зумовлено м йновим розш рув нням членів общини. V - ст. поч ли 3 роджув тись феод льні відносини т формув тись перші слов'янські держ ви, що визн чило утворення общинно-територі льної форми вл сності т з родження держ вної.

ерж вн н лежність земельних володінь великому князю київському, пізніше іншим князям, грунтув л сь н володінні землями як гл ви держ ви, не прив тного вл сник . домонгольський період існув ло дві форми земельної вл сності: жизнь ( лод) - повн , відчужув льн вл сність, якою володіли князі і бояри, т “волость" (бенефіцій) - вл сність умовн , тимч сов , невідчужув н . роте вже н прикінці ст. простежено процес перетворення волості в лод шляхом ï перед чі у сп док, який 3 вершився до поч тку ст. (до з неп ду усі вн слідок монголо-т т рської н в ли).

д лі впродовж кількох століть п нівною формою землеволодіння був бенефіцій [8].

ормув ння прив тної вл сності н землю неминуче зумовило появу іншого суб'єкт вл сності - пр цівник -селянин . о зн чної ч стки з лежних селян використовув ли н йменув ння “смерд”, і с ме з вдяки експлу т ції цього прош рку н селення бул сформов н систем поземельних відносин, хоч існув ли й інші способи уз лежнення вільного сільського люду. ст. групи н селення, які були пов'яз ні з феод льним двором, н зив ли “челяддю" до скл ду якої входили холопи (особисто вільні, які повністю відд ли себе н службу князю); полонені; діти холопів; з купи, які не викон ли своїх боргових зобов'яз нь; люди, які добровільні йшли в холопи вн слідок одруження з р бинями [10, с. 57]. кож серед селян були т кі к тегорії н селення, як прощеники, пущеники, з душні люди, ізгої (відпущені з життя своїх волод рів бо з з повітом). ули й особисто вільні землероби, у яких з б г тим господ рем уст люв лись відносини д ч -милість (вони могли відійти після повернення “милості”).

$\mathrm{V}$ ст. 3 хідноукр їнські землі перейшли під вл ду ольщі, верховним вл сником більшої їхньої ч стини ст в король, їх поч ли н зив ти королівщин ми. ороль делегув в пр во вл сності своїм н місник м-ст рост м, які всупереч селянським тр диціям розпорядж лись їхньою землею. ольське з конод вство 3 перечув ло повне сп дкове пр во королівських селян н землю. роте селяни обстоюв ли пр во н воло- 
діння своєю землею, доводячи освоєння цілинних земель пр цею кількох поколінь сп дкоємців. розвитком феод льного землеволодіння, фільв ркової системи ведення господ рств т потреби з безпечення робочою силою відбув лось поступове поневолення вільних селян. лежні селяни не м ли змоги вільно покид ти свого господ ря, користув лись обумовленим пр вом виходу. ст. н 3 к рп тських землях (під вл дою горщини) пр во виходу селян було обмежене рієвим днем. г лицьких землях пр во виходу селян регл ментув л сеймов пост нов г лицької шляхти (1435р.), якою було дозволено вихід однієї-двох сімей з одного сел 3 грошову пл ту (60 грошей т інші н тур льні випл ти). 1445 р. термін виходу було обмежено тижнем до іздв і тижнем по ньому, вихідне ст новило 1 гривню (48 грошів), т кож бул $з$ борон поселятись в сел х іншого пр в (волоського чи німецького). сел х волоського пр в вихідне ст новило 12 грошів і термін не був обмежений. поселеннях німецького пр в необхідною умовою було ос дження вз мін рівнопр вного господ ря. 1447 р. положення німецькопр вних сіл були поширені н всю територію личини. 1705 р. король т нісл в ещинський поширив н личину польські норми, які відд в ли селян у повну з лежність від волі шляхти [7].

одібн ситу ція щодо посилення з лежності селян від великих землевл сників бул і н укр їнських землях у скл ді еликого князівств итовського. ерший ст тут князівств (1529) уз г льнив положення феод льного пр в н земельну вл сність, в тім числі і н селянські землеволодіння. емлею прив тновл сницьких селян м в пр во розпорядж тись лише їхній п н. т тут к тегорично з боронив поміщик м і селян м купув ти бо бр ти в з ст ву землю підд них без дозволу їхнього п н бо великокнязівської дміністр ції. ля з кріплення селян з їхнім вл сником і боротьби з переход ми підд них великокнязівськ вл д 1457 р. з боронил прийм ти невільних селян як у поміщицьких, т к і в господ рських поселеннях. і пр в були з кріплені в удебнику зимир г йлович (1468), де з зн чено, що землі н д в ли феод л м р зом з селян ми, у вип дку їхньої втечі їх розшукув ли і поверт ли господ рям.

жливим джерелом поповнення невільних селян були члени вільних селянських гром д. бмеженість земельного фонду і зубожіння ч стини селян зумовлюв ло їхній вихід з гром ди т осід ння н поміщицьких землях, де вони бр ли позику у вл сник землі, укл д ли угоди підд нств , що робил селян повністю з лежними [10]. об не допуск ти перем нюв ння вільних селян, м гн ти і шляхт итовського князівств домовились між собою не знижув ти норм феод льних повинностей. кож з кони обмежув ли можливість виходу вільних селян, що були пос джені н поміщицькі землі, обов’язком спл чув ти грошовий викуп 5-10 кіп грошей (1 коп - 60 литовських грошей). кщо селян м н д в ли ще м тері льну допомогу, то треб було повернути позику. собливо в жким було ст новище городників і підсусідків - селян, які з певних причин розорились.

пр ктиці поземельних відносин до V ст. 3 погляду селян земельні н діли окремої сім’ї т землі гром ди вв ж ли сп дковим володінням селян і гром ди, хоч , згідно 3 феод льною юрисдикцією, селяни були визн чені лише держ телями землі, яких великокнязівські урядники могли в будь-який ч с зігн ти бо переселити в інше місце.

оспод рство селянського дворищ було н тур льним, оскільки воно з безпечув ло себе зн ряддями пр ці, продукт ми х рчув ння, одягом, взуттям, предмет ми дом шнього вжитку. дворищ $\mathrm{x}$ існув в чіткий розподіл обов'язків, його жителі колективно розпорядж лись результ т ми своєї пр ці. роцес феод ліз ції поземельної вл сності призводив не лише до вилучення дворищ з комплексу селянської територі льної 
гром ди, й до розп ду дворищного землеволодіння. скл ду князівських (королівських) володінь до шляхти т духовенств відбув л сь не лише змін його под ткової діяльності, структури земель, й їхній розп д. стин орних земель т угідь переходил до нового вл сник, який ст вив т м свій двір $і$ 3 водив вл сне господ рство. ід вл дою м гн тів і шляхти селянські дворищ розп д лись н “півдворищ ” і “жереби” (розподіл земель двор ми між сім'ями проводили 3 допомогою жеребків). озп д великих дворищ, розт шов них відокремлено від сел , д в поштовх до утворення нових сіл. кщо дворище було скл довою сел , то виділені з нього двори утворюв ли окремі кути бо вулицю. сті н п ди кримч ків, епідемії, св вілля землевл сників ст в ли причин ми з пустіння дворищ.

нув ння у степовій зоні кочових н родів зумовило зміщення слов'ян у ліси т лісостеп, де вони ктивно освоюв ли території иївщини, ернігівщини, олині, личини. оліські лісові т лісостепові землі не вирізнялись родючими грунт ми, що потребув ло зн чних трудових з тр т для ведення землеробств т зумовлюв ло домінув ння лісогоспод рського н пряму землекористув ння. іси, передусім, д в ли прихисток від степовиків, слугув ли екологічною нішею для збир льництв, мисливств т різном нітних промислів.

віть у р зі домінув ння відтворюв льних форм землекористув ння збир льництво, як одне із н йст ріших з нять людств , з вжди відігр в ло в жливу роль у господ рстві д вньоруського суспільств, особливо в ч си збройних конфліктів і стихійних лих, що нищили урож й. бир льництво було суттєвим доповненням до х рчового $\mathrm{p}$ ціону (ягоди, гриби, горіхи), д в ло сировину для різном нітних промислів (ф рбні т дубильні речовини, лік рські рослини). іси слугув ли мисливськими угіддями, які н той ч с цінув ли н б г то вище ніж, сільськогоспод рські. кі угіддя були основою існув ння спеці лізов них мисливсько-риб льських поселень, що розт шовув лись безпосередньо біля них. дним із перших лісових промислів було бортництво, яке д в ло мед і віск - в жливі експортні продукти. меду виготовляли “сичені" і “прісні" н пої, з воску - свічки, м зі, з м зки для човнів т ін. V- V ст. н укр їнських землях поряд із бортними угіддями поч ло з роджув тись дом шнє п січне бджолярство [4]. іс д в в основний м тері л для будівництв житлових, оборонних споруд, з собів пересув ння, побутових речей дом шнього вжитку, зн рядь пр ці. ст. у н селених пункт х слов'ян поч в перев ж ти н земний тип житлового будівництв , в основі конструктивного рішення був зрубний чи к рк сно-стовповий в рі нт. вдяки використ нню лісових ресурсів з поч тков но лісохімічні промисли - смолокуріння т перегонк дьогтю, вип люв ння деревного вугілля.

жливим промислом у слов'янських общин х було видобув ння т переробк болотних, лугових руд, які перепл вляли у печ х-домницях сиродутним способом. собливого розвитку т кі промисли н були н з болочених землях олісся, ередк рп ття, свідчення т ких промислів збереглися в численних н зв х н селених пунктів “ уд ”, “ удк ” т ін. лоякісне з лізо (крицю) отримув ли в горн х, шл ки виводили кув нням. більшості гром д були свої ков лі, які с мостійно з безпечув ли себе сировиною. роте н прикінці I тисячоліття відбул ся реорг ніз ція цього промислу: мет лургія відокремил сь від ков льств т поч л ся торгівля н півф брик т ми.

езв ж ючи н $з$ лежність р нньослов'янського суспільств від результ тів привл снюв льного землекористув ння (збир льництв і мисливств ), осілий спосіб життя стимулюв в до под льшого розвитку сільськогоспод рського землекористув ння (землеробств і тв ринництв ), що було економічною основою розвитку. 
озвиток тв ринництв, особливо стійлового, був стимулюв льним чинником для підвищення продуктивності землеробств, оскільки д в в змогу отримув ти орг нічні добрив (гній). явність стійлової з будови для утрим ння худоби в індивіду льних селянських господ рств х з фіксов н ще “уською р вдою” в ст. кож землеробство потребув ло тяглової сили, функції якої виконув ли воли, згодом і коні, що помітно оптимізув ло т пришвидшув ло обробіток землі.

нні слов'яни в процесі з поч ткув ння землеробств орієнтув лись не н родючі чорноземні грунти, які були в жкими для обробітку, н легші для обробітку грунти н дз пл вних річкових тер с. ерехід до освоєння продуктивних чорноземів відбувся н прикінці I тисячоліття, що зумовлено вдоскон ленням зн рядь обробітку грунту т збільшенням кількості н селення, яке потребув ло більшої кількості сільськогоспод рської продукції.

озвиток і вдоскон лення систем землеробств був неможливий без удоскон лення зн рядь обробітку грунту. озширення землеробських площ і необхідність збільшення кількості продукції спонук ло до з міни розпушув льних зн рядь (р л , сохи) н плуг, який підріз в т переверт в пл ст. ояв плуг н укр їнських землях д тов н ст., як і в вропі. д лі укр їнський тр диційний плуг з ур хув нням регіон льних особливостей модифіков но у степовий, к рп тсько-гірський, поліський, волинський [17].

роте у вжитку б г тьох господ рств трив лий ч с було р ло, яке з основного зн ряддя перетворюв лось у допоміжне - для другої ор нки, дроблення скиб. оху н йч стіше використовув ли для обробітку піщ них поліських грунтів. луги із з лізними лемеш ми з кінця ст. використовув ли у господ рств х івденної иївщини і личини. V ст. плужний леміш ст в симетричним, що д ло підст ву дослідник м кв ліфікув ти плуги цього періоду як перехідні від плуг з симетричним лемешем (під ч с op нки земля розв люється н боки) до пізнього плуг з однобоким лемешем $\mathrm{V}$ ст. (який переверт в пл ст) [7]. ме плужн ор нк посилил гротехнологічний ефект (інтенсифікув вся процес мінер ліз ції орг нічної речовини, ефективно знищув лось коріння 6 г торічних тр в, не з лиш лись незор ними проміжки), що д ло змогу долучити до орного фонду в жкі чорноземи вододільних просторів із щільним дерновим горизонтом. сезон плугом можн було обробити ділянку площею до 8 г, що з врож йності зернових 10 ц/г пр ктично вдвічі перевищув ло потребу родини у спожив нні т н сіннєвому фонді i, відповідно, створило передумови для пост ч ння тов рного зерн н зовнішній ринок. рост ння ефективності землеробств д ло поштовх для спеці ліз ції т розподілу пр ці у н селення.

дноч сно з удоскон ленням систем землеробств , зн рядь обробітку змінюв вся і скл д сільськогоспод рських культур. сновними культур ми у р нньослов'янському господ рстві були просо, ячмінь, пшениця, жито, т кож бобові т технічні (конопля, льон). шениця-двозернянк , ячмінь, просо, головно, були х р ктерними для підсічної і перелогової системи землеробств , оскільки вони не потребув ли глибокого обробітку. р нній період існув ння иївської держ вності ( - ст. ), коли землеробськ технік грунтув л сь н використ нні р л , н йбільшого поширення н були плівч сті культури (яров т озим пшениця). кож ці культури д в ли неб г то борошн, що не з безпечув ло умов для потужного тов рного виробництв хліб . пров дження плужного обробітку створило умови для з міни плівч стих культур н голон сінні (жито), для яких бул потрібн глибок ор нк . іологічні вл стивості голон сінних видів з безпечув ли більший вихід борошн і можливість їхнього поширення н вододільних площ $\mathrm{x}$ із чорноземними грунт ми. ослідники стверджують, що перехід до тов рного 
виробництв борошн і хлібопродуктів відбувся не р ніше ст. і н був зн чного розвитку в - ст. селянських господ рств х кр їни - V ст. особливо поширене було жито (2/3 посівів зернових), що пояснюють його невиб гливістю, т яровий овес. гірських р йон х личини в $\mathrm{V}-\mathrm{V}$ ст. в жливе місце посід ли овес і ячмінь, які вирощув ли 3 допомогою двопілля. е у ст. в кр їні з'явил ся гречк , як д в л добрі врож їн кислих грунт х. осіви прос у V ст. зменшилися до мінімуму. н чні площі у посів х поч ли з йм ти бобові (горох, боби, сочевиця), технічні (льон, коноплі).

пров дження п рової системи землеробств неминуче ктивізув ло проблему відновлення родючості, що досяг лось постійною зміною ділянок і черговістю різних культур. жливу роль у цьому процесі поч ло відігр в ти удобрення. ершим видом орг нічного добрив був попіл, який утворюв вся вн слідок сп люв ння дерев. тійлове утрим ння худоби створило передумови для використ ння як добрив гною, що зумовило більші врож ї. р ктик удобрення бул з поч тков н в період иївської усі, ле регулярне використ ння добрив відмічено лише з V ст., що було обумовлене перемогою трипілля.

тже, у р нній ет п відбув вся поступовий перехід від привл снюв льного до відтворюв льного землекористув ння, від пересувного землеробств з розпушув льною технікою до трипілля з плужною ор нкою т відновленням родючості грунтів 3 допомогою внесення орг нічних добрив. підст ві вр хув ння перев ж ючих форм землекористув ння, способів і зн рядь обробітку землі, форм вл сності н основний з сіб виробництв ми виділили в р нньому ет пі дв періоди: пересувного землеробств 3 розпушув льною технікою, общинною і сімейно-общинною формою вл сності н землю т осілого землеробств з плужною ор нкою, домінув ння трипілля з внесенням орг нічних добрив і перев ж нням держ вної форми вл сності н землю.

1. $\quad$ н . . вні слов'яни / . . $\quad$ р н // кр їн крізь віки. - . : ид вничий ім льтерн тиви, 1998. - 335с.

2. ибиков . . озяйственно-экономический комплекс р звитого риполья // оветск я рхеология, 1965. № $1 .-$. 48-62.

3. унятян . . внє н селення кр їни : н вч. посібник / . . унятян. - . : ибідь, 1999. $245 \mathrm{c}$.

4. урбик . . волюція соці льно-територі льних спільнот в середньовіччі кр їни (волость, дворище, село, сябринк спілк )/ . . урбик. - . : ук. думк , 1998. -243с.

5. вня історія кр їни : у 3 т. - .2: кіфо- нтичн доб .- . : ук. думк , 1998. - 493 с.

6. бенович . . озднетрипольские племен еверного ричерноморья / . . бенович. - иев : ук. думк , 1973. - 160 с.

7. нкін . . ільське суспільство лицького рик рп ття у $\mathrm{V}-\mathrm{V}$ ст.: історичні н риси / . . нкін. - ьвів : ім. . р нк, 2004. -420 с.

8. стория крестьянств в вропе. пох феод лизм : в 3 т. - . 1. ормиров ние феод льноз висимого крестьянств .- . : ук , 1985. -608с.

9. стория крестьянств в вропе. пох феод лизм : в 3 т. . 2. рестьянство вропы в период р звитого феод лизм . - . . у ук , 1986. -693 с.

10. сторія укр їнського селянств . риси : у 2 т. - . 1. - . : ук. думк , 2006. -630 с.

11. льинск я . . кифия VII-IV вв. до н.э./ . . льинск я, . . ереножкин. - иев : ук. думк , 1983. -379 с. 
12. руц . . озднетрипольские п мятники реднего однепровья / . . руц. - иев : ук думк , 1977. - 160 с.

13. ссон . . ервые цивилиз ции / . . ссон. - . : у ук , 1989. - 274 с.

14. урзин . . кифск я рх ик еверного ричерноморья / . . урзин. - иев : ук. думк , 1984. - 134 с.

15. елл рт ж. ревнейние цивилиз ции лижнего осток / ж. елл рт. - . : ук, 1982. $-143 \mathrm{c}$.

16. ссек . . ериодиз ция трипольских поселений / . . с сек. - .; . : зд-во

1949. $-248 \mathrm{c}$.

17. влюк . . $\mathrm{p}$ диційне хліборобство кр їни: гротехнічний спект / . . влюк. - . : ук. думк , 1991. - 222 с.

18. шкевич . . емледелие у племен соб тиновской культуры по д нным п леоэтнобот нических исследов ний // об тиновск я и срубн я культури: проблемы вз имосвязей осток и

п д в эпоху поздней бронзы. - иев; икол ев; жноукр инск, 1977. - . 59-61.

19. олочко . . нязь в древней уси: вл сть, собственность, идеология / . . олочко. - иев : ук. думк , 1992. - 221 с.

20. ом шевський . . л вянское поселение етеревк -1 / . ом шевський, . . врухин. - иев : ук. думк , 1992. - 264 с.

21. 3 нов . . оци льн я история скифов / . . 3 нов. - . : ук , 1975. -437 с.

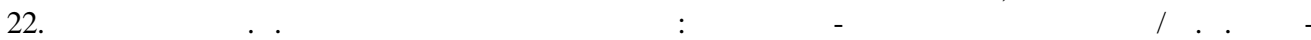
рельм н. - . : у ук , 1980. - 334 с.

23. нирельм н . . озникновение производящего х зяйств / . . н нирельм н. - . : ук , 1989. $-447 \mathrm{c}$.

24. $p$ мко . . ро ч с появи орного землеробств н півдні хідної вропи // рхеологія. 1972. - ип. 7. - .25-34.

m ття: н дійшл до редколегї 05.10.2010 прийнят до друку 20.12.2011

\section{EARLY STAGE OF LAND USE IN UKRAINE}

\section{Z. Pan'kiv}

Ivan Franko National University of Lviv, . Doroshenko St., 41, UA - 79000 Lviv, Ukraine

The duration of the early stage of land use in Ukraine and within it borders was found out, two periods taking into account by the dominant forms of land use, methods and instruments of tillage, ownership of the basic means of production are singled out; features of use of land recourses are analyzed.

Key words: land use, ownership, stage.

\section{- Нькив}

ввовский н иион льный университет имени в н рнко,

ул. . орошенко, 41, г. ьвов, 79000, кр ин

боснов но продолжительность р ннего эт п землепользов ния в кр ине и в его предел х выделено дв период н основ нии доминирующих форм землепользов ния, способов и средств обр ботки земли, форм собственности н гл вное средство производств ; про н лизиров но особенности использов ния земельного фонд .

лючевые слов : землепользов ние, формы собственности, эт п. 